\title{
The Levels of Bio-Indicator Bacteria in the Fresh Water Resources of Eastern Anatolia Region of Turkey
}

\author{
Gülşen Altuğ ${ }^{1 *}$, Mine Çardak ${ }^{2}$, Pelin S. Çiftçi Türetken ${ }^{1}$, Serap Koşal Şahin ${ }^{1}$ and Samet Kalkan ${ }^{3}$ \\ ${ }^{1}$ Department of Marine Biology, Fisheries Faculty, Istanbul University, Istanbul, Turkey \\ ${ }^{2}$ Department of Fisheries Technology, Çanakkale School of Applied Disciplines, Canakkale Onsekiz Mart \\ University, Çanakkale, Turkey \\ ${ }^{3}$ Department of Marine Biology, Fisheries Faculty, Recep Tayyip Erdoğan University, Rize, Turkey \\ Email: galtug@istanbul.edu.tr
}

\begin{abstract}
In this study, anthropogenic influences on the natural fresh water sources regarding the levels of indicator bacteria were investigated in the Eastern Anatolian, Turkey. The surface water samples $(0-30 \mathrm{~cm})$ were collected seasonally in the period between November 2008 and October 2009 . The levels of total and faecal coliform bacteria were tested using membrane filtration technique. The detected coliform bacteria in the sampling region, where livestock raising activities are intense, revealed the region under the influences of bacteriological pollution inputs. The results also showed that freshwater sources of the region carry a potential risk for human health. This is the first data that can be used in the assessment of bacterial risks of these water sources in the Tunceli and Munzur Valley of the Eastern Anatolia, Turkey. Bacteriological monitoring studies are needed to be established for detecting of pollution sources and sustainable use of natural water resources.
\end{abstract}

Keywords: Fecal coliform, total coliform, bacteriological pollution, fresh water, eastern anatolian.

\section{Introduction}

Bacteria have a crucial role in biochemical cycling and food webs in natural aquatic environments. They metabolize pollution factors by using complex chemical reactions [1], [2], [3]. However, depending on land-based pollution stress such as "industrial activity, terrestrial wastes, and overpopulation" increasing bacteria levels may cause undesirable conditions. The increase of bacteria and occurrence of possible pathogens may cause serious problems related to ecosystem and human health and sustainable uses of natural resources [4].

Since freshwater ecosystems are critical environments for environmental protection and sustainable use of natural resources, monitoring and controlling on them is essential. Though documents reported about various indicator organism types in aquatic environments [5], [6], [7], [8], classical approach for understanding bacterial load is research to the level of indicator bacteria such as coliform/fecal coliform/Escherichia coli all over the world. While total coliform bacteria have been appropriated as an indicator for detecting bacterial pollution levels, fecal coliform bacteria have been accepted as the sewage-sourced indicator in aquatic environments.

The Munzur Valley that is the largest national park in Turkey is located near the Munzur Mountains within Tunceli province in eastern Anatolia. As with most surface waters, groundwater in this region is caused by snow and rainfall entering the ground and underground waters, flowing from higher to lower. Consequently, there are many streams in the region and the Keban Dam Lake is the most important water resource in this area. The other important rivers such as Munzur, Mercan, Pülümür, Peri and Tahar which are $1300 \mathrm{~m}$ above sea level have a great importance for the area. Several streams (Kizılca, Kuru, Boğaz, Arel, Paşadüzü, Değirmendere, Aksu, Mercan and Çayüstü) fall into Munzur River. Due to the fact that livestock raising is the most important economic activity in the area, the water resources play a key role in the region.

There are a few biological studies related to fish, trichoptera and mollusca fauna of the streams of this region such as: "the meat yield and chemical composition of Salmo trutta macrostigma caught in 
Munzur River" [9], the distribution of larval trichopteran assemblages [10] and mollusca fauna of the streams of Tunceli [11].

In this study, the levels of bioindicator total coliform and faecal coliform bacteria were investigated for the first time with an aim to detect bacterial load in the surface water samples taken from freshwater resources of Tunceli and Munzur Valley of Eastern Anatolia region, Turkey, in the period between 2008 and 2009 .

\section{$2 \quad$ Materials and Methods}

\subsection{Study Area}

Eastern Anatolia region, located in the easternmost part of Anatolia, is the largest one of the seven geographical areas of Turkey. The region has severe winters with heavy snowfalls. The sampling stations were chosen from the points named "lake" among the people which formed as a result of the glacial troughs filled with water due to snow and rain.

Ten sampling points (DG1: Koyun Lake 1. DG2: Yeşilyazı 1, DG3: Değirmendere1, DG4: Koyun Lake 2, DG5: Değirmendere 2, DG6: Yeşilyazı 2, DG7: Mercan 2, DG8: Mercan 1, DG9: National Park 1, DG10: National Park 2) were selected with the aim of determining the level of bacteriological pollution since they are the main natural water resources used in human and animal husbandry activities in the region.

Coordinates of the stations where surface water samples were taken from East Anatolian, were shown in Table 1.

Table 1. Coordinates of the stations where surface water samples were taken from Eastern Anatolia in the period between November 2008 and October 2009.

\begin{tabular}{l|l|lll|l}
\hline Code & Local Name & Coordinates & & Type \\
\hline DG1 & Koyun Lake1 & $39^{\circ} 21^{\prime} 638^{\prime \prime}$ & $\mathrm{N}, 39^{\circ} 13^{\prime} 505^{\prime \prime}$ & E & Lake \\
\hline DG2 & Yeşilyazı 1 & $38^{\circ} 58^{\prime} 620^{\prime \prime}$ & $\mathrm{N}, 39^{\circ} 41^{\prime} 720^{\prime \prime}$ & $\mathrm{E}$ & Stream \\
\hline DG3 & Değirmendere 1 & $39^{\circ} 19^{\prime} 873^{\prime \prime}$ & $\mathrm{N}, 39^{\circ} 03^{\prime} 253^{\prime \prime}$ & $\mathrm{E}$ & Stream \\
\hline DG4 & Koyun Lake 2 & $39^{\circ} 21^{\prime} 373^{\prime \prime}$ & $\mathrm{N}, 39^{\circ} 13^{\prime} 624^{\prime \prime}$ & $\mathrm{E}$ & Lake \\
\hline DG5 & Değirmendere 2 & $39^{\circ} 10^{\prime} 677^{\prime \prime}$ & $\mathrm{N}, 39^{\circ} 27^{\prime} 691^{\prime \prime}$ & $\mathrm{E}$ & Pond \\
\hline DG6 & Yeşilyazı 2 & $38^{\circ} 58^{\prime} 865^{\prime \prime}$ & $\mathrm{N}, 39^{\circ} 44^{\prime} 924^{\prime \prime}$ & $\mathrm{E}$ & Stream \\
\hline DG7 & Mercan 2 & $39^{\circ} 19^{\prime} 873^{\prime \prime}$ & $\mathrm{N}, 39^{\circ} 02^{\prime} 250^{\prime \prime}$ & $\mathrm{E}$ & Stream \\
\hline DG8 & Mercan 1 & $39^{\circ} 22^{\prime} 196^{\prime \prime}$ & $\mathrm{N}, 39^{\circ} 10^{\prime} 252^{\prime \prime}$ & $\mathrm{E}$ & Pond \\
\hline DG9 & National Park 1 & $39^{\circ} 20^{\prime} 163^{\prime \prime}$ & $\mathrm{N}, 39^{\circ} 04^{\prime} 832^{\prime \prime}$ & $\mathrm{E}$ & Stream \\
\hline DG10 & National Park 2 & $39^{\circ} 25^{\prime} 503^{\prime \prime}$ & $\mathrm{N}, 39^{\circ} 21^{\prime} 062^{\prime \prime}$ & $\mathrm{E}$ & Pond \\
\hline
\end{tabular}

\section{$2.2 \quad$ Sampling}

In this study, bio-indicator bacteria were investigated to determine bacteriological pollution levels of the surface waters of Yeşilyazı, Değirmendere, Mercan and Koyun Lakes and also Munzur Valley National Park Lake. The water samples were taken under aseptic conditions from the surface $(0-30 \mathrm{~cm})$ seasonally in the period between November 2008 and October 2009. The sampling locations were shown in Figure 1. 


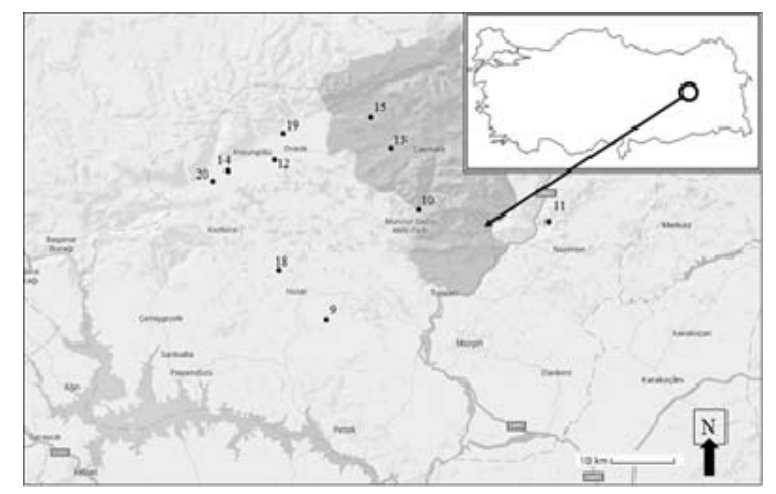

Figure 1. The map showing sampling area; Eastern Anatolia region of Turkey. Stations; DG1: Koyun Lake 1. DG2: Yeşilyazı 1, DG3: Değirmendere1, DG4: Koyun Lake 2, DG5: Değirmendere 2, DG6: Yeşilyazı 2, DG7: Mercan 2, DG8: Mercan 1, DG9: National Park 1, DG10: National Park 2.

\subsection{Bacteriological Analyses}

The samples were diluted serially and filtered through membrane filters $(0.45 \mu \mathrm{m}$, Millipore) by using membrane filtration method in triplicate. Samples were placed on m-Endo and m-FC for $24 \mathrm{~h}$ incubation period (at $37 \pm 0.1{ }^{\circ} \mathrm{C}$ and $44.5 \pm 0.1{ }^{\circ} \mathrm{C}$ ). The metallic green-gold sheen and red-pink colonies on m-Endo were chosen as suspected total coliform bacteria. Confirmation test for coliform bacteria was applied using cytochrome oxidase (API Strep, BioMereux) and oxidase-negative colonies were considered. While blue colonies on $\mathrm{m}$-FC were determined as suspected of fecal coliform after cytochrome oxidase (API Strep, BioMereux) and indole (HIMEDIA) tests, oxidase-negative and indolpositive colonies were considered. After confirmation tests of suspected colonies, the number of bacteria was counted as colony forming units averagely $(\mathrm{CFU} / 100 \mathrm{ml})[12]$.

\section{$3 \quad$ Results}

Bacteriological data obtained from the water samples was evaluated regarding "Surface Water Quality Management Regulations" published in the Turkish Official Gazette No. 28483 on 30.11.2012. According to this regulation limit values for the total coliform and fecal coliform bacteria were assessed to be 100 $\mathrm{CFU}$ (colony formed unit) $/ 100 \mathrm{ml}$ and $10 \mathrm{CFU} / 100 \mathrm{ml}$, respectively. Bacterial values were given logarithmically $(\log 10)$ in the figures.

The criterion for the comparison of the water quality of the study area was chosen in terms of the use of these water resources as potable water, recreational potential and animal production and farm needs using Annex 5 of the Turkish "Surface Water Quality Management Regulations".

The levels of indicator bacteria detected in the samples taken from the surface waters in autumn 2008 were shown using logarithmically values $(\log 10)$ in Figure 2. 


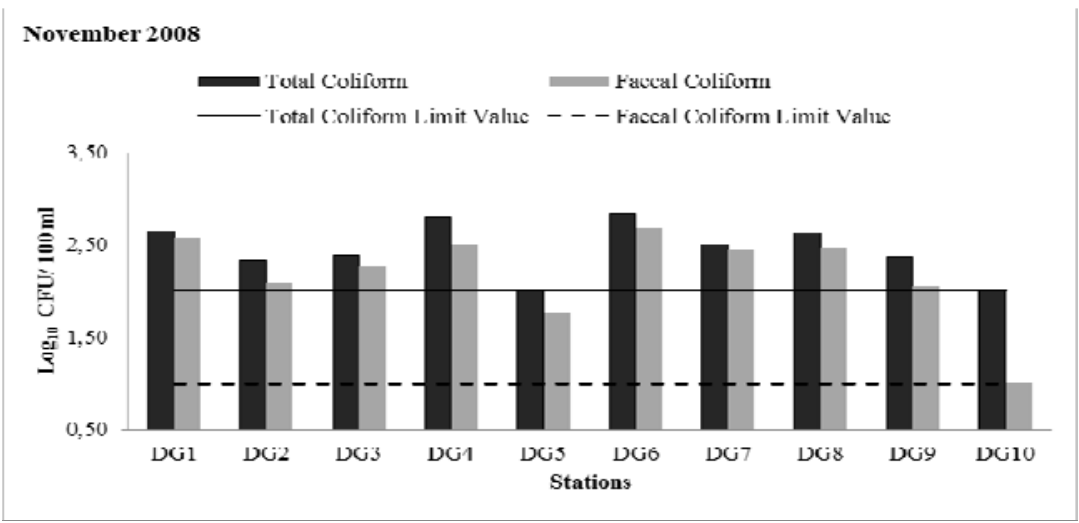

Figure 2. The levels of indicator bacteria detected in the samples taken from surface waters in November 2008. DG1: Koyun Lake 1. DG2: Yeşilyazı 1, DG3: Değirmendere1, DG4: Koyun Lake 2, DG5: Değirmendere 2, DG6: Yeşilyazı 2, DG7: Mercan 2, DG8: Mercan 1, DG9: National Park 1, DG10: National Park 2.

While the water samples taken from all stations displayed higher bacteria values than the national permissible limits, bacteria counts detected slightly lower than the standard values only in the samples taken from the station DG5 (Değirmendere pond) in November 2008.

The highest indicator bacteria counts were detected in the station DG6 (Yeşilyazı Stream). The second highest bacteria were detected in the samples taken from station DG4 (Koyun Stream) in November 2008.

The levels of indicator bacteria detected in the samples taken from surface waters in February 2009 were shown in Figure 3.

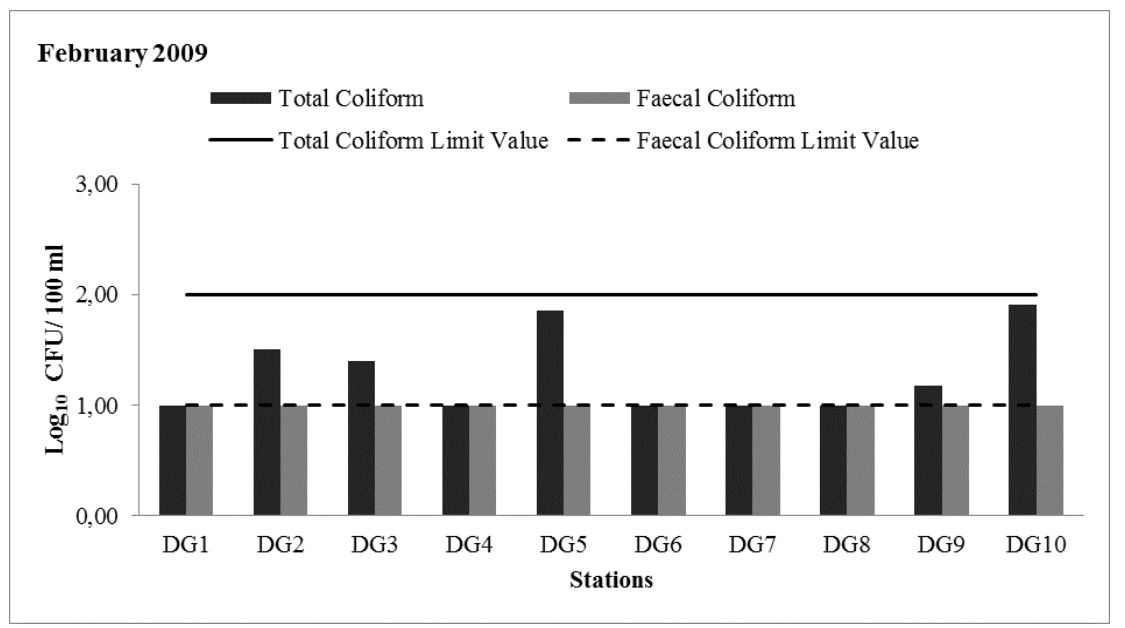

Figure 3. The levels of indicator bacteria detected in the samples taken from surface waters in February 2009. DG1: Koyun Lake 1. DG2: Yeşilyazı 1, DG3: Değirmendere1, DG4: Koyun Lake 2, DG5: Değirmendere 2, DG6: Yeşilyazı 2, DG7: Mercan 2, DG8: Mercan 1, DG9: National Park 1, DG10: National Park 2.

The levels of indicator bacteria were recorded under the national permissible limits in the samples taken from sampling points in February 2009.

The levels of indicator bacteria detected in the samples taken from surface waters in June 2009 were shown in Figure 4. 


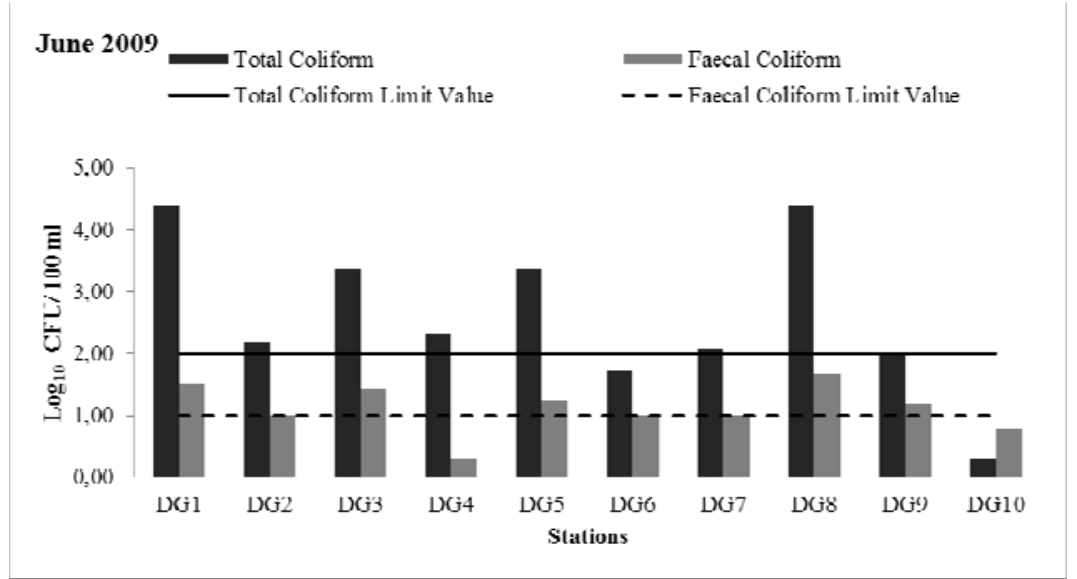

Figure 4. The levels of indicator bacteria detected in the samples taken from surface waters in June 2009. DG1: Koyun Lake 1. DG2: Yeşilyazı 1, DG3: Değirmendere1, DG4: Koyun Lake 2, DG5: Değirmendere 2, DG6: Yeşilyazı 2, DG7: Mercan 2, DG8: Mercan 1, DG9: National Park 1, DG10: National Park 2.

The levels of indicator bacteria detected in the samples taken from surface waters in October 2009 were shown in Figure 5.

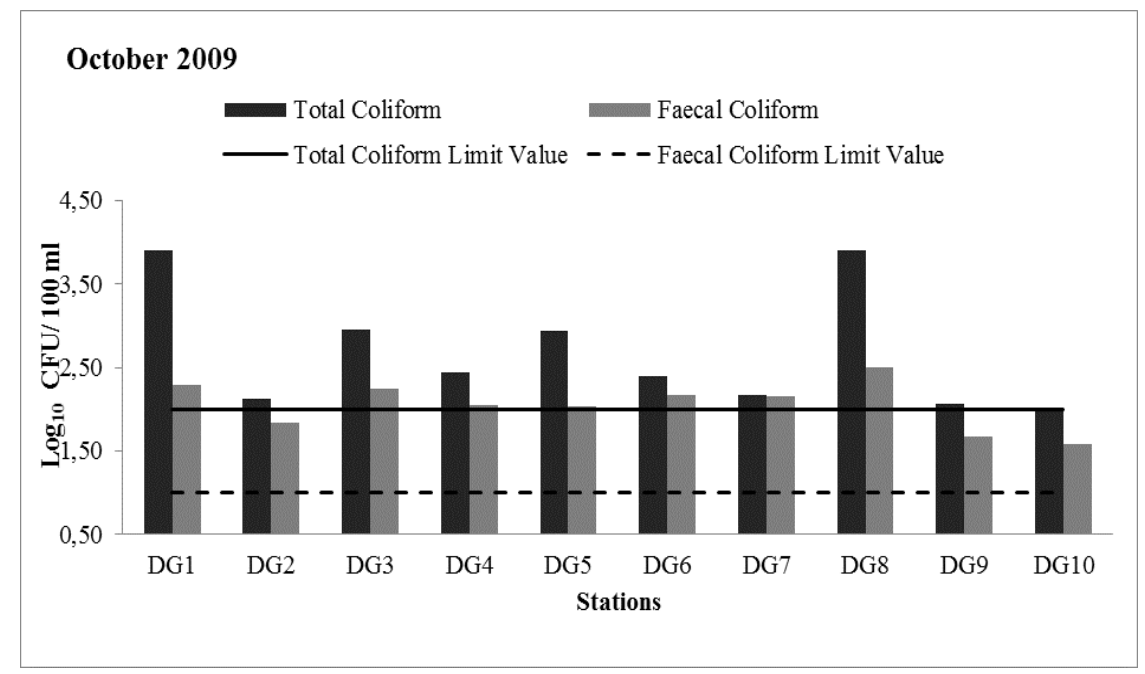

Figure 5. The levels of indicator bacteria detected in the samples taken from surface waters in October 2009. DG1: Koyun Lake 1. DG2: Yeşilyazı 1, DG3: Değirmendere1, DG4: Koyun Lake 2, DG5: Değirmendere 2, DG6: Yeşilyazı 2, DG7: Mercan 2, DG8: Mercan 1, DG9: National Park 1, DG10: National Park 2.

The highest levels of bacteria were recorded in the samples taken from DG1 and DG8 stations both in June and October 2009.

While total coliform values were found to be lower than national values only two stations (DG6, DG10) in June 2009, four stations (DG2, DG4, DG5 and DG8) displayed higher indicator bacteria levels than national criteria in the samples taken from in autumn season.

While indicator bacteria levels were recorded to be lower than the national limit values in the samples taken from all stations in the winter season, the total coliform counts were recorded to be higher than limit values in all station in October 2009. The levels of indicator bacteria were also recorded above national parameters in 8 out of 10 stations in the spring season. The lowest level of bacteria was recorded in the samples which were taken from the stations DG3, DG7, and DG9 during the study period. 


\section{Discussion}

In this study, in order to investigate the bacteriological quality of the water resources in the Eastern Anatolia Region (Turkey) various water sources formed by rainwater, snow and other rainfall were investigated.

Determination of bacteriological quality of water sources is crucial to describe the environmental and public health status. The risk-based approach to water quality is of great importance in the world. Water resources surrounded by residential areas are under bacteriological contamination risks which can lead to problems due to the domestic wastes, agricultural and livestock activities etc. Identification of pollution factors is important for protecting ecological, biological and economic features of natural water resources. It was reported that major sources of fecal bacteria, including pathogens are discharges of wastewater to fresh waters and coastal seawaters [13]. Because of natural water resources must be bacteriologically clean, pollution point sources and nonpoint resources need to be detected considerably. There are various parameters determined by own regulations of countries to monitoring and protect natural sources related to the safeguarding of natural bacteriological norms. The Member States of the European Union or individual countries apply water quality criteria and standards [14], [15], [16]. The World Health Organization's (WHO) water quality guidelines reported the risk-based approach to water quality management. These guidelines describe the management of microbial threats from source to exposure [17].

Natural water resources have been formed according to the laws of environmental protection of quality criteria all over the world. The classes of inland water resources have been determined based on "Water Pollution Control Regulation" in Turkey. The findings provided first bacteriological data for this region, were evaluated according to Turkish "Surface Water Quality Management Regulations" [18].

In this study, detected indicator bacteria levels and occurrence of fecal contamination implied that there was a potential for the pathogenic bacteria in the region. Especially, the presence of high counts of indicator bacteria in Koyun Lake, Değirmendere and Mercan Dam showed that these resources carry a potential risk for human health in this region. While this situation was evaluated taking animal husbandry into consideration, the lowest levels of bacteria were recorded in the region of National Park and Yeşilyazı Stream.

Bacteriological data of the investigated stations was evaluated regarding "Surface Water Quality Management Regulations", published in the Turkish Official Gazette No. 28483 on 30.11.2012. The water quality in these stations investigated was found between Class I and Class II according to the Turkish "Surface Water Quality Regulation". Additionally, due to the bacteria levels detected higher than $1000 \mathrm{CFU} / 100 \mathrm{ml}$ in the summer season in the stations of the DG1, DG3, DG5 and DG8, these stations were evaluated as prone to eutrophication. The stations of the DG1 and DG8 also displayed similar trends in autumn sampling season. This indicated that these areas needed long-term monitoring studies on bacterial contamination.

In order to protect the water quality and to ensure the health of aquatic life in this dam, it is required to make regular observations and to monitor the parameters affecting the water quality and aquatic life.

The data obtained has constituted the first fundamental data that may be used to assess the bacterial risk of the region. The ways to protect water resources from negative impacts of agricultural and livestock activities should be developed. However, there is a need for long-term and more detailed studies in order to protect the region from bacteriological risks that may occur due to point and nonpoint pollution sources. The precautions should be put into action immediately in order to protect the region from possible pathogen contamination.

\section{References}

1. F. Azam, T. Fenchel, J.G. Field, J.S. Gray, L.A. Meyer-Reil and F. Thingstad, "The ecological role of microbes in the sea," Marine Ecol. Prog. Ser. 10:257-263, 1983.

2. J. B. Cotner, and B. A. Biddanda, "Small players, large role: microbial influence on biogeochemical processes in pelagic aquatic ecosystem," Ecosystems 5:105-121, 2002.

3. C. W. Burns, and L.M. Galbraith, "Relating planktonic microbial food web structure in lentic freshwater ecosystems to water quality and land use," J. Plankt. Res. 29:127-139, 2007. 
4. M. F. Craun, G. F. Craun, R. L. Calderon, M. J. Beach, "Waterborne outbreaks reported in the United States," J Water Health.; 4 Suppl 2:19-30, 2006.

5. D. M. Gordon, "Geographical structure and host specificity in bacteria and the implications for tracing the source of coliform contamination. Microbiology," 147 (5):1079-85, 2001.

6. D. Malakoff, "Water quality: microbiologists on the trail of polluting bacteria," Science; 4 (5564): 2352-2353, 2002.

7. P. K. Pandey, M. L. Soupir, C. R. Rehmann, "A model for predicting resuspension of Escherichia coli from streambed sediments," Water Res. 2012 Jan 1; 46(1):115-26, 2012.

8. P.K. Pandey, and M.L. Soupir, "Assessing the impacts of E. coli laden streambed sediment on E. coli loads over a range of flows and sediment characteristics," J Am Water Resour Assoc.; 4(6):1261-1269, 2013.

9. M. Duman, M. Dartay, F. Yüksel, "Meat Yield and Chemical Composition of the Brown Trout, Salmo trutta macrostigma (Dumeril, 1858), Living in Munzur River," Frat Univ. Journal of Science 23 (1), 41-45, 2011.

10.M. Zeybek, and S. Kosal Sahin, "The Distribution of Trichoptera Assemblages in Relation to Environmental Variables in the Streams of Tunceli (Turkey)," Fresenius Environmental Bulletin Volume 25 - No. 11/2016, p. 4972-4981, 2016.

11.S. Koşal Şahin, and M. Zeybek, "Distribution of Mollusca Fauna in the Streams of Tunceli Province (East Anatolia, Turkey) and its Relationship with Some Physicochemical Parameters," Turkish Journal of Fisheries and Aquatic Sciences 16: 187-195. DOI: 10.4194/1303-2712-v16_1_19, 2016.

12.APHA, Standard methods for the examination of water and wastewater 20th edition Clesceri, L.S., A.E Greenberg and A.D Eaton (eds). American Public Health Association, American Water Works Association and Water Environment Federation. Washington, D.C., 2000.

13.WHO (World Health Organization) Guidelines for Drinking-water Quality, Incorporating 1st and 2nd Addenda, Volume 1, Recommendations. 3rd ed. WHO; Geneva, Switzerland, 2008.

14.W.O.K. Grabow, Waterborne Diseases: Update on Water Quality Assessment and Control. Water SA. 22:193202, 1996.

15.EPA, Environmental Protection Agency (EPA) Parameters of Water Quality: Interpretation and Standards ISBN 1-84096-015-3, 2001.

16.P. S. Cabral João, "Water Microbiology," Bacterial Pathogens and Water Int J Environ Res Public Health. 7(10): 3657-3703, 2010.

17.WHO (World Health Organization) Quantitative microbial risk assessment, Application for water safety management ISBN: 978924156537 November, 2016.

18.WPCR, Water Pollution Control Regulation of the Turkish Republic, Turkish Federal Register, Official Gazette No. 28483, 30 November, 2012. 